\title{
ポリ塩化ビニル製輸液容器と菜物との相互作用*1
}

\author{
矢内原洋, 村上克幸, 内田研三
}

愛媛大学医学部附属病院薬郕部*2

\section{Interactions between Drugs and Polyvinyl Chloride Infusion Bags*1}

\author{
HIROSHI YANAIHARA, KATSUYUKI MURAKAMI and KENZO UCHIDA \\ Department of Pharmacy, Ehime University Hospital*2
}

(Received January 21, 1985)

12 kinds of injectable drugs were investigated for adsorption to polyvinyl chloride intravenous fluid bags. The solutions were assayed by spectrophotometry or high performance liquid chromatography (HPLC). Diazepam and prochlorperazine dimaleate in unbuffered aqueous solution, and diazepam, clomipramine $\mathrm{HCl}$, promethazine $\mathrm{HCl}$, prochlorperazine dimaleate, clorpromazine $\mathrm{HCl}$ and levomepromazine $\mathrm{HCl}$ and levomepromazine $\mathrm{HCl}$ in buffered solution ( $\mathrm{pH}$ 7.4) showed significant adsorption.

In all drugs studied, adsorption increased with time while loss of the drugs were not related to initial concentration. Adsorption also increased in parallel with a rise in temperature. Loss of diazepam was unaffected by $\mathrm{pH}$. On the other hand, the extent of loss was greater at higher $\mathrm{pH}$ levels in levomepromazine $\mathrm{HCl}$, promethazine $\mathrm{HCl}$ and clomipramine $\mathrm{HCl}$.

Keywords_adsorption; polyvinyl chloride; diazepam; clomipramine $\mathrm{HCl}$; prochlorperazine dimaleate; chlorpromazine $\mathrm{HCl}$; promethazine $\mathrm{HCl}$; levomepromazine $\mathrm{HCl}$

近年, ポリ塩化ビニル (PVC) 等の軟質プラスチック 製の輸液容器が広く使用されるようになってきた。ク口 一ズドシステムで使用できるなどの利点も多いが，ある 種の薬物はプラスチック表面に吸着し, 残存率が低下す ることが知られている．PVC 製輸液容器への薬物の吸 着に関しては多数の報告1 19) があり, ベンゾジアゼピン 誘導体, 4 9) ${ }^{4 \sim}$ トグリセリン10 13) およびインシュリ ン14,15)等の薬物が PVC に吸着する性質を有することが 確認されている.

今回, 12 種類の神経系用薬の注射剂を用い, PVC 製 輸液容器への吸着に関して検討したので報告する.

\section{実 験 方 法}

\section{1. 予剑験}

ポリ塩化ビニル製輸液容器, トラベノール社製 Viaflex (Lot No. OHPO $25 \mathrm{SO}$ ) の $5 \mathrm{~cm} \times 5 \mathrm{~cm}$ 切片, 厚さ

*1 日本薬学会第 104 年会病院薬学部会（仙台, 1984 年 3 月）で発表.

*2 愛媛県温泉郡重信町大字志津川: Shizukawa, Shigenobu-cho, Onsen-gun, Ehime, 791-02 Japan
$0.37 \mathrm{~mm}$, 重量 $1.2 \mathrm{~g}$ を洗浄し, 蒸留水ですすぎ, 乾燥 させたものを試料とした.

市販のアナフラニール注 $25 \mathrm{mg} / 2 \mathrm{ml}$ (塩酸クロミプ ラミン, チバガイギー), コントミン注 $25 \mathrm{mg} / 5 \mathrm{ml}$ (塩 酸クロルプロマジン, 吉富製薬), ノハミミン注 $5 \mathrm{mg} / 1 \mathrm{ml}$ (マレイン酸プロクロルペラジン, 大日本製薬), ピレ チア注 $25 \mathrm{mg} / 1 \mathrm{ml}$ (塩酸プロメタシンン, 塩野義), アレ ビフチン注 $250 \mathrm{mg} / 5 \mathrm{ml}$ (フェニトインナトリウム, 大 日本), ダイアモックス注 $500 \mathrm{mg} / \mathrm{V}$ (アセタゾラミド, レダリー), セルシン注 $10 \mathrm{mg} / 2 \mathrm{ml}$ (ジアゼパム, 武田 薬品), ケタラール注 $200 \mathrm{mg} / 20 \mathrm{ml}$ (塩酸ケタミン, 三 共), キシロカイン注 $100 \mathrm{mg} / 20 \mathrm{ml}$ (塩酸リドカイン, 藤沢薬品), マーカイン注 $25 \mathrm{mg} / 20 \mathrm{ml}$ (塩酸ブピバカ イン, 吉富製薬), インミタール注 $250 \mathrm{mg} / 2.5 \mathrm{ml}$ (アモ バルビタールナトリウム, 日本新薬) の12種類を用い, それぞれ蒸留水および $\mathrm{pH} 7.4,0.05 \mathrm{M}$ リン酸緩衝液に て希釈し, 所定の溶液とした.なおフェニトインは $\mathrm{pH}$ 7.4 で溶解しないため, $\mathrm{pH} 7.4$ での試験からは除外し た.

PVC 切片を薬物溶液 $100 \mathrm{ml}$ 中に浸し, 遮光条件下 $25 \pm 2^{\circ} \mathrm{C}$ で 24 時間放置後, 薬物濃度を吸光度法により 
Table 1. Loss of Drugs from Solution during Storage with PVC Piece for 24 Hours

\begin{tabular}{|c|c|c|c|c|c|}
\hline & $\lambda(\mathrm{nm})$ & $\begin{array}{c}\text { Initial conc. } \\
(\mu g / \mathrm{ml})\end{array}$ & $\begin{array}{c}\text { Unbuf } \\
\mathrm{pH}\end{array}$ & $\begin{array}{l}\text { red solu. } \\
\text { \% Lost }\end{array}$ & $\begin{array}{l}\text { Buffered solu. } \\
\% \text { Lost }\end{array}$ \\
\hline Clomipramine $\mathrm{HCl}$ & 252 & 20 & 5.0 & 0 & 54.4 \\
\hline Prochlorperazine Dimal. & 254 & 10 & 5.6 & 12.4 & 64.2 \\
\hline Chlorpromazine $\mathrm{HCl}$ & 254 & 10 & 5.4 & 9.4 & 72.1 \\
\hline Promethazine $\mathrm{HCl}$ & 249 & 10 & 5.3 & 4.0 & 44.5 \\
\hline Levomepromazine $\mathrm{HCl}$ & 250 & 10 & 5.3 & 2.5 & 59.1 \\
\hline Phenytoin & 258 & 200 & 9.0 & 0 & - \\
\hline Acetazol amide & 265 & 20 & 8.4 & 0 & 0 \\
\hline Diazepam & 242 & 10 & 5.0 & 17.5 & 17.0 \\
\hline Ketamine $\mathrm{HCl}$ & 269 & 200 & 5.0 & 0 & 0 \\
\hline Lidocaine $\mathrm{HCl}$ & 271 & 50 & 5.2 & 2.9 & 1.5 \\
\hline Bupivacaine $\mathrm{HCl}$ & 288 & 50 & 5.1 & 5.7 & 3.5 \\
\hline Amobarbital $\mathrm{Na}$ & 265 & 500 & 9.1 & 0 & 0 \\
\hline
\end{tabular}

測定した．対照には同様に操作した薬物溶液を用いた。 薬物初濃度, $\mathrm{pH}$ および測定波長は Table 1 亿示す. 試験は 3 回行い平均値を求めた.

\section{2. 海洨容器の材要による莱物の吸洋}

2-1. ガラス $(100 \mathrm{ml})$, ポリオレフィン (PO, 100 $\mathrm{ml})$ および PVC $(1000 \mathrm{ml})$, Viaflex, 製の輸液容器に, 塩酸レボメプロマジンおよびジアゼパムは $10 \mu \mathrm{g} / \mathrm{ml}$, 塩 酸クロミプラミンは $20 \mu \mathrm{g} / \mathrm{ml}$ の $\mathrm{pH} 7.4$ に調製した溶 液を入れ， $25 \pm 2^{\circ} \mathrm{C} て ゙ 24$ 時間放置後の薬物濃度を測定 し, 各容器への薬物の吸着率を求めた。

2-2. Viaflex, Terupack-1 (テルモ, PVC) および Terupack-2 (テルモ, EVA) の3 種の軟質プラスチッ ク製輸夜容器の $5 \mathrm{~cm} \times 5 \mathrm{~cm}$ 切片を $10 \mu \mathrm{g} / \mathrm{ml}$ の塩酸 ボメプロマジンおよび塩酸プロメタジン溶液 $100 \mathrm{ml}$, $\mathrm{pH} 7.4$ に漫し $25 \pm 2^{\circ} \mathrm{C}$ で 24 時間放置後, 薬物濃度の 測定を行った. なお Terupack-1 の $5 \times 5 \mathrm{~cm}$ 切片は厚 さ $0.42 \mathrm{~mm}$, 重量 $0.95 \mathrm{~g}$, Terupack-2 は厚さ $0.38 \mathrm{~mm}$, 重量 $1.20 \mathrm{~g}$ のるのを用いた.

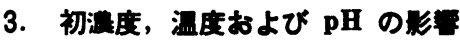

予試験で PVC の吸着が認められた薬物のらち数種を 用い, 吸着におよぼす初漕度, 温度および $\mathrm{pH}$ の影響を 検討した. Viaflex の $5 \mathrm{~cm} \times 10 \mathrm{~cm}$ 切片を薬物溶液 100 $\mathrm{m} 1$ 飞漫し，3，6，10および 24 時間後の薬物濃度を測 定し, 薬物残存率の経時的变化を観察した. 初濃度, $\mathrm{pH}$ および温度は実験の目的に応じて設定した。

\section{PVC 面程と吸兼象との网俰}

Viaflexを $3.1 \mathrm{~cm}^{2}$ から $100 \mathrm{~cm}^{2}$ までの任意の大き
さに切断したものを， $20 \mu \mathrm{g} / \mathrm{ml}$ の塩酸クロミプラミン 溶液 $100 \mathrm{ml}, \mathrm{pH} 7.4$ 飞浸し, $25 \pm 2^{\circ} \mathrm{C}$ で 24 時間放置 後, 薬物濃度を測定し, PVC 面積と吸着率の関係につ いて検討した。

\section{PVC 切片からの菓物の再溶出}

$5 \mathrm{~cm} \times 10 \mathrm{~cm}$ の Viaflex 切片を $20 \mathrm{\mu g} / \mathrm{ml}$ のジアせ パム溶液に浸し, 一定時間放置後, ジアゼパム濃度を測 定し, $0.65 \sim 0.70 \mathrm{mg}$ および $1.3 \sim 1.4 \mathrm{mg}$ のジアぜパ ムが吸着したと考兄られる Viaflex 切片を，ジアゼパム 溶液中から取り出し, 蒸留水ですすいだ後, 蒸留水およ びェタノール $100 \mathrm{ml}$ 中に浸し, $25 \pm 2^{\circ} \mathrm{C}$ で振とうしな がら放置し，経時的にジアゼパム濃度を測定し，Viaflex に吸着したジアせパムのエタノールおよび蒸留水に対す る再溶出について検討した.

\section{6. 莱物筷度の測定}

予試験ではギルフォード 250 型分光光度計を用い, 吸 光度法で薬物濃度を測定した。ジアゼパム注は添加剤の 影響を考虑し，予試験以外では高速液体クロマトグラフ ィーにより測定した. その他の薬物は予試験と同様吸光 度法により測定した. ジアゼパムの高速液体クロマトグ ラフィーは, カラム; $\mu$-Bondapak C 18, 溶媒; メタ, 一ル: 水 (75:25), 測定波長 $254 \mathrm{~nm}$, 流速 $1 \mathrm{ml} / \mathrm{min}$ の条件で行った.

\section{結果および考寮}

\section{1. 予侙験}

Table 1 に示すように, 蒸留水中では塩酸プロクロル 
ペラジンおよびジアセ゚ハムで，pH 7.4 のリン酸緩衙液 中では塩酸クロルブロマジンなど，4種のフェノチアジ ン誘導体，塩酸クロミブラミンおよびジフゼパムで10\% 以上の薬物濃度の減少が認められ，これは薬物が PVC 表面に吸着したためと考えられる.溶液の $\mathrm{pH}$ により残 存率に差が生じた薬物は塩酸クロミブラミンおよび 4 種 のフェノチアジン誘導体であり, ジぜパムでは差は認 められなかった.

なお試験中いずれの場合においてる外観変化はみられ ず，pH の著明な変動す認められなかった．薬物濃度の 測定を吸光度法で行ったが，添加郕の影響が考光られる ため，ここに示した受着率は見かけ上の值と思われる。

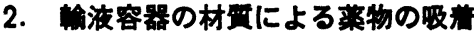

1) PVC 容器中では塩酸レボィプロマジン, ジフセ パムおよび塩酸クロミプラミンで各々著明な残存率の低 下が認められたが，ガラスおよびボリオレフィンでは認 められず，これらの薬物はガラスおよびポリオレフィン には吸着しないが，PVC には吸着する性質を有するこ とが明らかになった (Table 2)。

2） Table 3 亿示すように, 塩酸レボメブロマジンお よび塩酸プロメタジンでとすに 3 種の軟質ブラスチック に吸着し，残存率の低下がみられた。残存率は 3 種のブ ラスチックで各々異なっており，同一材質のものでも× 一カーにより，また材質の違いにより吸着に差が生じる と思われる。

\section{3. 初灌度の影零}

PVC 切片を 5,10 おび $20 \mu \mathrm{g} / \mathrm{ml}$ のジアゼパム溶 液に浸し， $25 \pm 2{ }^{\circ} \mathrm{C}$ で放置した場合の経時的な残存率の

Table 2. Adsorption of Drugs in Plastic and Glass Containers

\begin{tabular}{llll}
\hline \multicolumn{1}{c}{ Drug } & \multicolumn{3}{c}{ \% of initial concentration } \\
& Glass & P O & P V C \\
\hline Levomepromazine $\mathrm{HCl}$ & 100 & 100 & 42.8 \\
Diazepam & 100 & 98.7 & 59.2 \\
Clomipramine $\mathrm{HCl}$ & 100 & 100 & 49.3 \\
\hline
\end{tabular}

変化を Fig. 1 亿示す. ジアぜハムムの残存率は徐々に低 下する傾向を示したが，低下曲線は最初は急であるが以 後なだらかになった。これはブラスチック表面の薬物に 対する結合点が飽和され，溶液中の薬物と平衡達した 後, プラスチックマトリックス内に薬物が取り込まれ， 新たな結合点が生じるためではないかと思われる。

Fig. 1 に示すよらに試験した瀑度の範囲内では初浱 度の影響はみられなかった．同様の試験を10，20および $40 \mu \mathrm{g} / \mathrm{ml}$ の塩酸クロミブラミン, および 10,25 および $50 \mathrm{\mu g} / \mathrm{ml}$ の塩酸レボメプロマジンを用い行ったが，い ずれの場合も初瀑度の影稫は認められなかった。

\section{4. 温度の影些}

$10 \mu \mathrm{g} / \mathrm{ml}, \mathrm{pH} 7.4$ の塩酸レボメブロマジン溶液に PVC 切片を浸し， $4^{\circ} \mathrm{C}, 15^{\circ} \mathrm{C}$ おび $25^{\circ} \mathrm{C}$ で放置した 場合，24時間後の残存率は $4^{\circ} \mathrm{C}$ では $69.1 \%, 15^{\circ} \mathrm{C}$ て $42.2 \%, 25^{\circ} \mathrm{C}$ で $18.8 \%$ と温度が低くなるに従い残存率 が高くなる傾向を示した (Fig. 2). 同様の結果はジフ ぜパムおよび塩酸クロミプラミンを用いた試験です得ら れ，温度によりブラスチックの薬物に対する親和性が変 化するのではないかと思われる。

\section{5. $\mathrm{pH}$ の影霖}

$\mathrm{pH} 5.8, \mathrm{pH} 6.6$ および $\mathrm{pH} 7.4$ 亿調制した $10 \mu \mathrm{g} / \mathrm{ml}$ のジフゼパム溶液中に PVC 切片を浸し $25 \pm 2{ }^{\circ} \mathrm{C}$ で放 置した場合，Fig. 3 に示すように pH の変化はジアぜ パムの吸着には影響をおよぼさなかった。

一方 $20 \mu \mathrm{g} / \mathrm{ml}$ の塩酸クロミプラミンを用い, 同様の

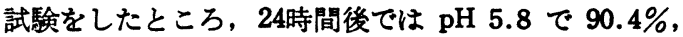
$\mathrm{pH} 6.6$ で $58.6 \%, \mathrm{pH} 7.4$ で $25.5 \%$ と $\mathrm{pH}$ 上昇に伴 い残存率が低下する傾向が認められた（Fig. 4)，また 同様の結果は塩酸レボメプロマジンおよび塩酸プロメタ ジンを用いた試験からも得られた。

Polack ら 2) は薬物のイオン化率扰よび脂溶性が吸着 現象に関して重要な要素であると報告しており，今回の 結果からすイオン化率すなわち溶解性により吸着率が変 化することが明らかになった。

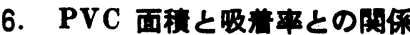

Fig. 5 に示すように PVC 面積が大きくなるに従い

Table 3. Adsorption of Drugs in Various Plastic Containers

\begin{tabular}{lccc}
\hline \hline \multirow{2}{*}{ Drug } & \multicolumn{3}{c}{$\begin{array}{c}\text { \% of Initial Concentration } \\
\text { Container Brand }\end{array}$} \\
& Viaflex (PVC) & Terupack-1 (PVC) & Terupack-2 (EVA) \\
\hline Levomepromazine HCT & 40.9 & 45.8 & 54.7 \\
Promethazine HCl & 55.5 & 60.8 & 67.1 \\
\hline
\end{tabular}




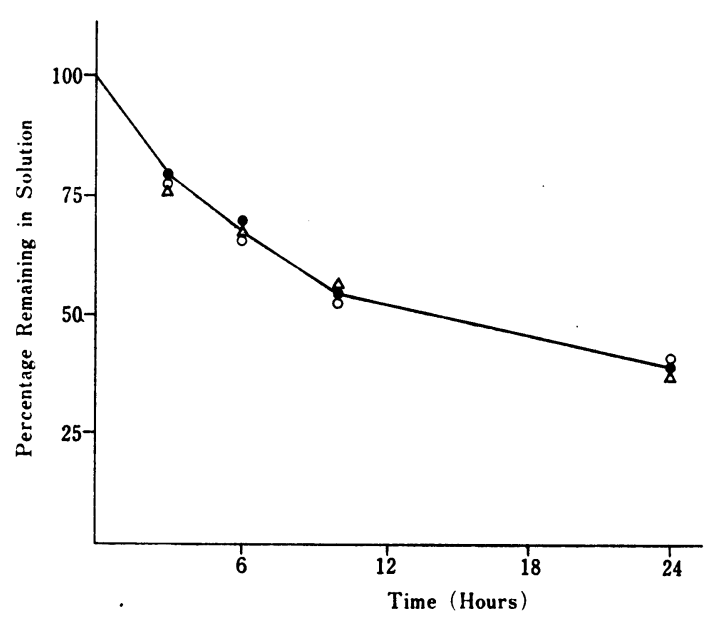

Fig. 1. Effect of Initial Concentration on Adsorption of Diazepam

$\bigcirc 20 \mu \mathrm{g} / \mathrm{ml}, \quad 10 \mu \mathrm{g} / \mathrm{ml}, \triangle 5 \mu \mathrm{g} / \mathrm{ml}$

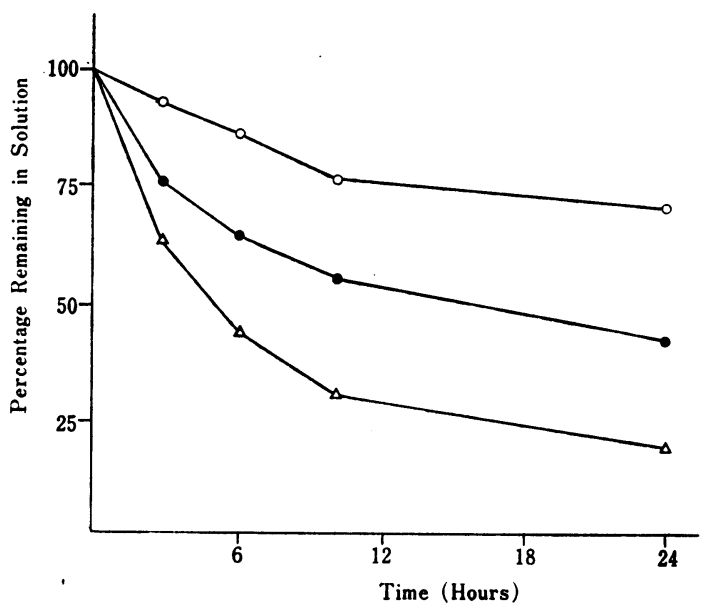

Fig. 2. Effect of Temperature on Adsorption of Levomepromazine $\mathrm{HCl}$

$\bigcirc 4^{\circ} \mathrm{C}, 15^{\circ} \mathrm{C}, \triangle 25^{\circ} \mathrm{C}$

吸着率は減少し，一方 PVC $1 \mathrm{~cm}^{2}$ あたりに吸着した塩 酸クロミブラミン量梳大きくなる傾向を示した．PVC 面積を小さくしてす $1 \mathrm{~cm}^{2}$ あたりに吸着する薬物量は一 定にはならず，飽和状態の確認はできなかった。

\section{7. 菲物の PVC 切片からの再演出}

ジアゼハムの PVC 切片からの再溶出曲線を Fig. 6 に示す. PVC 切片に吸着したジアゼハム量に网わらず 溶出率は一定であり, 蒸留水に対してょりるエタノール に対してよく溶出した。溶出率は 6 時間後にだいたい平 衡状態になり，24時間後の浴出率は蒸留水には17.0\%，

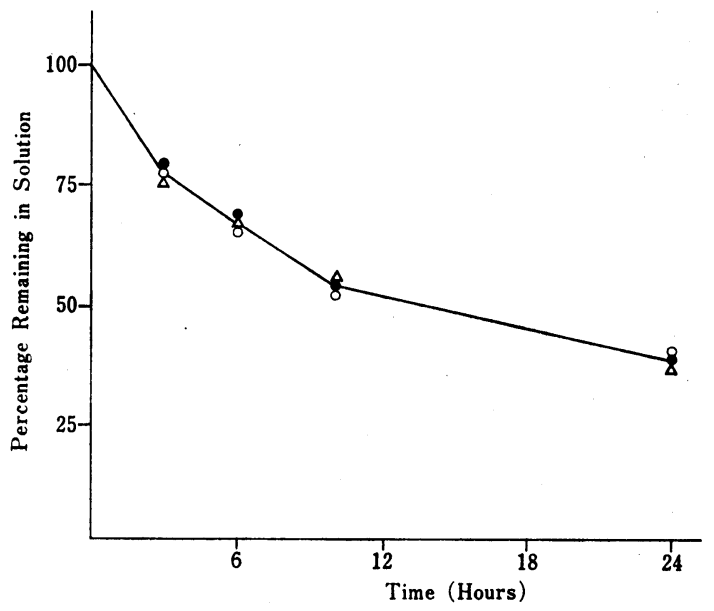

Fig. 3. Effect of $\mathrm{pH}$ of Solution on Adsorption of Diazepam

$\bigcirc \mathrm{pH} 5.8, \bigcirc \mathrm{pH} 6.6, \triangle \mathrm{pH} 7.4$

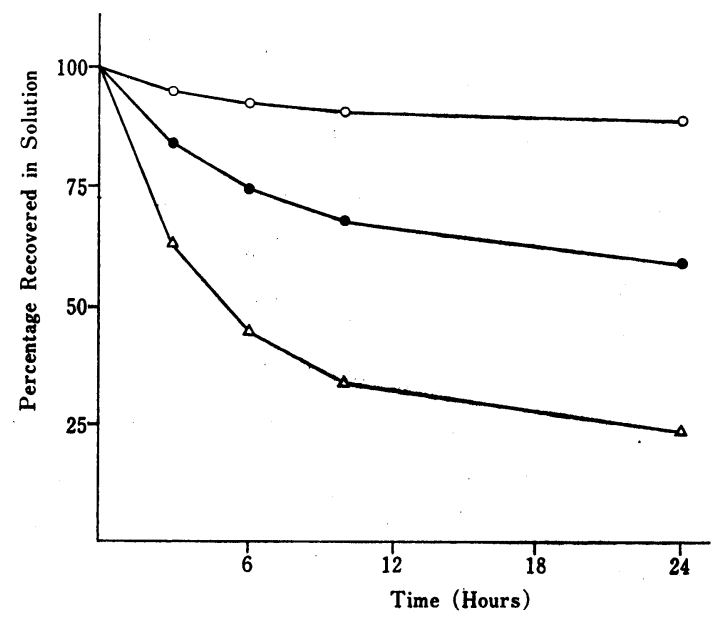

Fig. 4. Effect of $\mathrm{pH}$ of Solution on Adsorption of Clomipramine $\mathrm{HCl}$

$\bigcirc \mathrm{pH}$ 5.8, $\mathrm{pH}$ 6.6, $\triangle \mathrm{pH} 7.4$

エタノールには65.0\%であった.

桔

â

市販の注射靔を蒸留水で希釈した溶液ではジアゼパム およびマレイン酸プロクロルペラジンで PVC への吸着 が認められ，また pH 7.4 のリン酸綬街液で希釈した溶 液では塩酸クロミブラミン, ジアゼハム, マレイン酸ブ ロクロルペラジン, 塩酸ブロメタジンおよび塩酸レボメ プロマジンで PVCへの吸着が認められた.

PVC への薬物の呂着は薬液と PVC の接触時間およ 


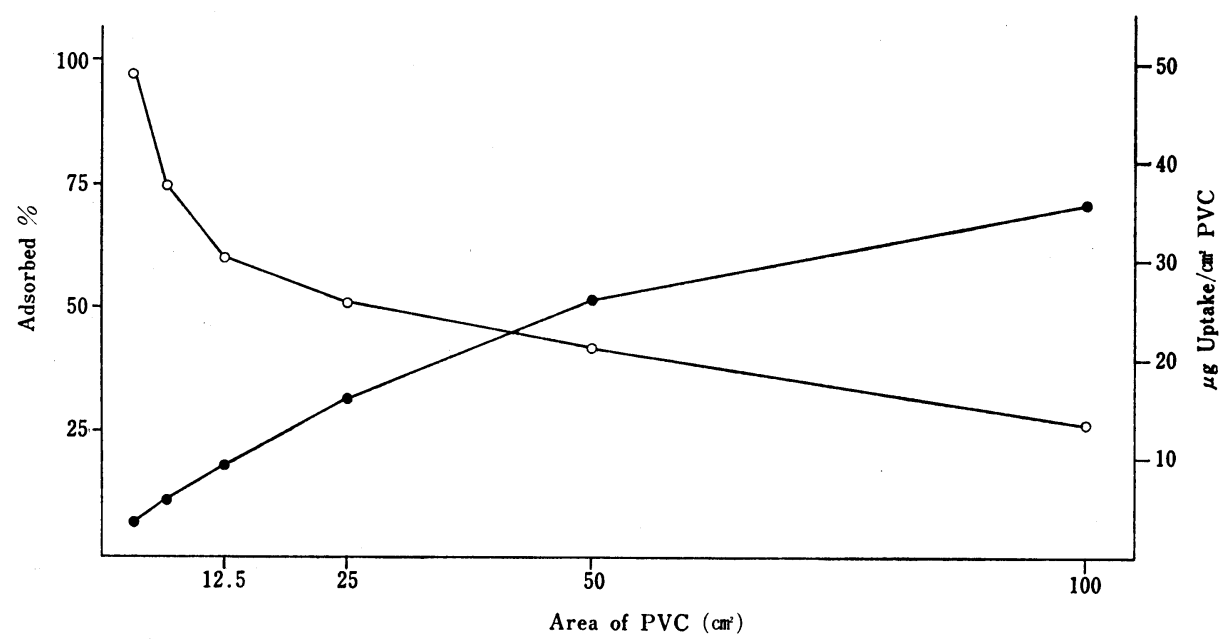

Fig. 5. Relationship of Clomipramine $\mathrm{HCl}$ Loss and Area of PVC $\bigcirc$ Uptake $/ \mathrm{cm}^{2}$ PVC, Adsorbed \%

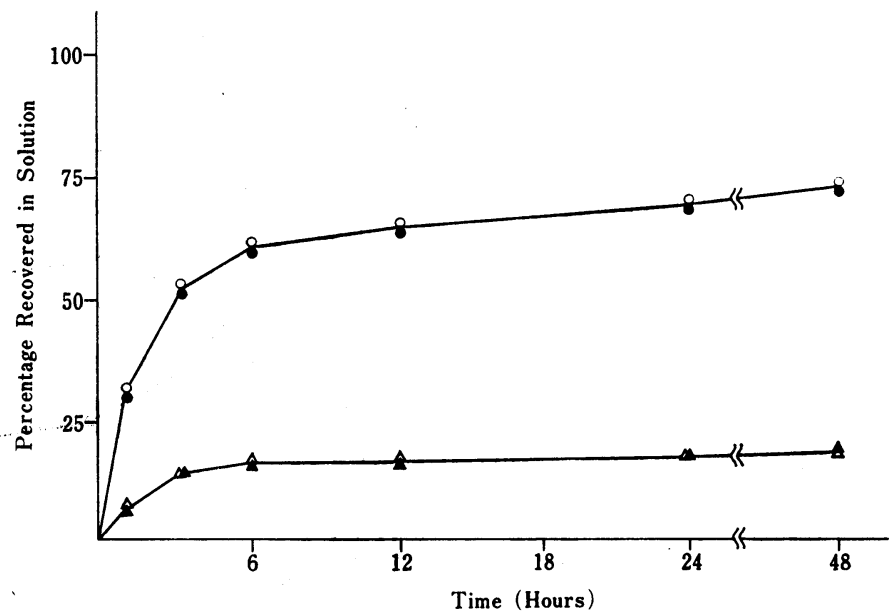

Fig. 6. Dissolution of Diazepam from PVC Piece to Ethanol and Distilled Water; Dissolution to Ethanol, $\bigcirc 1.3 \sim 1.4 \mathrm{mg}, \bigcirc 0.65 \sim 0.7 \mathrm{mg}$, Dissolution to Distilled Water, $\triangle 1.3 \sim 1.4 \mathrm{mg}, \triangle 0.65 \sim 0.7 \mathrm{mg}$

び接触面積の增加に伴い增加した．試験した濃度の範囲 内では薬物初濃度の影響はみられなかった。保存温度が 低くなるに従い吸着率は減少した．塩酸クロミプラミン および塩酸プロメタジン等の塩基性薬物では $\mathrm{pH} \mathrm{5.8〜}$ 7.4 の範囲内で $\mathrm{pH}$ 上昇に伴い吸着率は增加したが，ジ アゼパムでは吸着率に変化は認められなかった。

PVC への薬物の吸着には薬物の脂溶性扰よびイオン 化率が重要な因子であると考号られており，一般に脂溶 性が高く，使用する $\mathrm{pH}$ 域でイオン化率の低い薬物を軟 質プラスチック製の輸夜容器に入れて使用する際は，吸 着の問題汇関して配虑する必要があると思われる。
文

1) P.Moorhatch and W. L. Chiou: Am. J. Hosp. Pharm., 31, 72 (1974).

2) E.A. Kowaluk, M.S. Roberts, H.D. Blackburn and A.E. Polack: ibid., 38, 1308 (1981).

3) E.A. Kowaluk, M.S. Roberts and A.E. Polack: ibid., 39, 460 (1982).

4) W.A. Parker and M.E. MacCara: ibid., 37, 496 (1980).

5) N.A. Mason, S.Cline, M.L. Hyneck, R.R. Berardi, N. F. H. Ho and G.L. Flynn: ibid., 38, 1449 (1981). 
6) J.K. Yliruusi, A.G. Sothmann, R.H. Laine, R.A.Rajasilta and E.R. Kristoffersson: ibid., 39, 1018 (1982).

7) E.A. Kowaluk, M.S. Roberts and A.E. Po lack: ibid., 40, 417 (1983).

8) R.L. Nation, L.P. Hackett and L.J. Duscl: ibid., 40, 1692 (1983).

9) D.W.Newton, W.A.Narducci, W.A. Leet and C. T. Ueda: ibid., 40, 424 (1983).

10) P.A. COssum, A.J. Galbraith, M.S. Roberts and G.W. Boyd: The Lancet, August 12 (1978).

11) D. M.Baaske, A.H.Amann, D. M. Wagenknecht, M. Mooers, J.E. Carter, H. J. Hoyt and R.G. Stoll: Am. J. Hosp. Pharm., 37, 201 (1980).

12) D. M. Baaske, A.H. Amann, D. M. Wagenknecht,
N. N. Karnatz, J. Wong, J.E.Carter and R.G. Stoll: ibid., 39,121 (1982).

13) J.V.St. Peter and T.G. Cochran: ibid., 39, 1328 (1982).

14) F.J.Whalen, W.K. LeCain and C.J. Latiolais: ibid., 36, 330 (1979).

15) J.I. Hirsch, J.H. Wood and R.B. Thomas: ibid., 38, 995 (1981).

16) T.E. Lackner, D. Baldus, C.D. Butler, C. Amyx and G.Kessler: ibid., 40, 97 (1983).

17) J.A. Benvenuto, R.W. Anderson, K.Kerkof, R. G. Smith and T. L. Loo: ibid., 38, 1914 (1981).

18) E. Tomlinson and L. Malspeis: J. Pharm. Sci., 71, 1121 (1982).

19）市川和恵, 羽田真佐子, 香西典子: 病院薬学, 2 , 88 (1976).
劇胆汁分泌促進剤

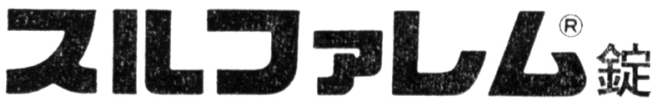

アネトールトリチオン $12.5 \mathrm{mg} /$ 錠 含有

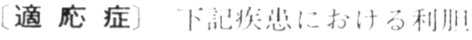

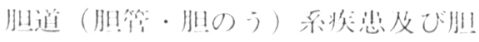

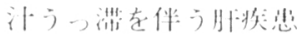

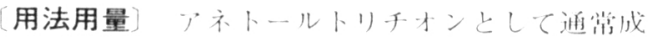

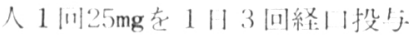

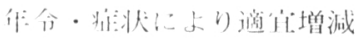

薬理作用 (1) 侻: 1 11 作: 月

(2) 月1機能賦话作朋) (IILL 中 S S 值 I:

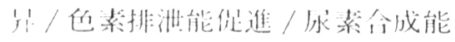

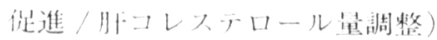

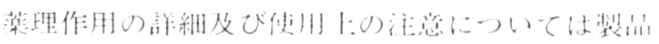
源付文皆圭ご参照下さい。

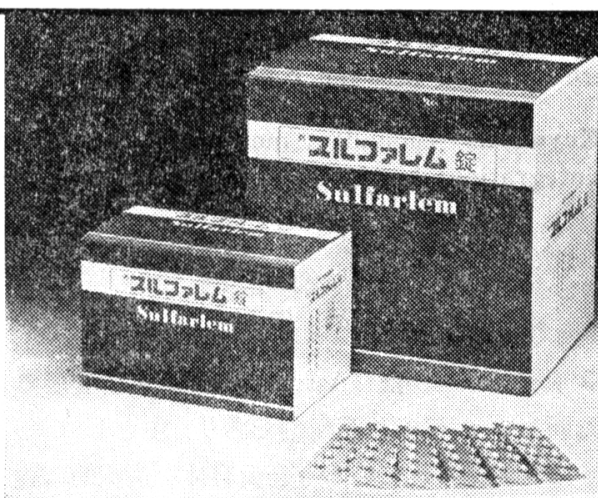

包装] 1,200 錠 6,000 錠

(P'TP) 10 錠 $\times 12010$ 錠 $\times 600$

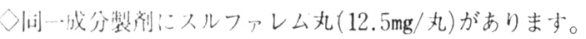

規制区分：劇 薬

薬価基準収載品

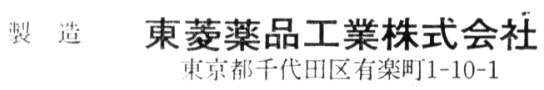

提淿 ラ テ マ 社(フランス)

旡管元

唗桑蔡品工業株式会社。

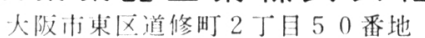

